\title{
ANALYZING THE OPPORTUNITY FOR OPEN BANKING IN BRAZIL
}

\author{
Rafael Dan Schur ${ }^{1}$ and Larissa Campostrini Sily ${ }^{2}$ \\ ${ }^{1}$ FGV EAESP / EY, Brazil \\ ${ }^{2}$ Independent researcher, Brazil
}

\begin{abstract}
Open Banking sets forth a new way of accessing financial products and services through digital platforms that gathers developers, financial institutions and consumers through application programming interfaces (APIs). On April 24, 2019, the Brazilian Central Bank issued Announcement No. 33.455, disclosing the basic requirements for the implementation in Brazil of the Open Financial System, also known as Open Banking. According to the Brazilian Central Bank, this initiative aims to increase the efficiency of the financial system by bringing more competition to this business environment and making it more inclusive, without compromising consumer safety and protection. Open Banking, as defined by the Central Bank, is "the sharing of data, products and services by financial institutions and other authorized entities, at the discretion of their clients - for data related to them - by opening and integrating information systems infrastructure and platforms in a safe, agile and convenient way". The incipient regulation and the institutional reaction of banks and tech companies regarding their participation in this new model for the provision of financial services have also raised some questions. Will this regulation be enough for the adoption of Open Banking? What potential factors drive clients to adhere to this new financial business model - or prevent them from doing so? Which digital financial services Brazilian consumers already use? The goal of this article is to help find answers for these questions, exploring the evolution of digital financial services up to now and understanding the consumer sentiment regarding this new service model, based on a survey conducted between January and May 2019, in which 1,024 Brazilian banking consumers answered on their consumption of digital financial services and their sentiment regarding Open Banking. The assessment indicates that the adoption of digital banking services based on an open platform will be higher, the higher are the assurances to consumers regarding their privacy and the risk management of third parties who connect to the platform. Additional studies to evaluate in further detail the incentives and barriers for the adoption of banking services in an open platform and, as a result, to analyze the business model alternatives that financial institutions may adopt and that the Brazilian Central Bank should regulate will certainly contribute for the effective implementation of Open Banking in Brazil in the short term.
\end{abstract}

\section{KEYWORDS}

Consumer Sentiment, Open Banking, FinTech, Digital Financial Services, Bank-as-a-Platform

\section{INTRODUCTION}

On April 24, 2019, the Brazilian Central Bank issued Announcement No. 33.455, disclosing the basic requirements for the implementation in Brazil of the Open Financial System, also known as Open Banking. According to the Brazilian Central Bank, this initiative aims to increase the efficiency of the financial system by bringing more competition to this business environment and making it more inclusive, without compromising consumer safety and protection (Brazilian Central Bank, 2019). Open Banking, as defined by the Central Bank, is "the sharing of data, products and services by financial institutions and other authorized entities, at the discretion of their clients - for data related to them - by opening and integrating information systems infrastructure and platforms in a safe, agile and convenient way". The incipient regulation and the institutional reaction of banks and tech companies regarding their participation in this new model for the provision of financial services have also raised some questions. Will this regulation be enough for the adoption of Open Banking? What potential factors drive clients to adhere to this new financial business model - or prevent them from doing so? Which digital financial services Brazilian consumers already use? The goal of this article is to help find answers for these questions, exploring the evolution of digital financial services up to now and understanding the consumer sentiment regarding this new service model. 


\section{THE EVOLUTION OF MOBILE BANKING}

On January 9, 2007, Apple launched the iPhone in the United States of America. The product was then launched in Germany, the UK and France and, after that, smartphones conquered the world. The revolution caused by smartphones is still being understood across several sectors of society and, particularly, by the financial system. In 2012, smartphones were already the next big thing and there was no doubt among banks that it was necessary to have an app for mobile phones. However, the largest part of the financial institutions saw these new models of mobile phones as another channel, an evolution of the model already implanted in alternative service channels. Mobile banking, or m-banking, is among the latest advances in the creation of digital service channels that already included ATMs and internet banking. Developed by a partnership between Deutsche Bank and the company Paybox, m-banking was used for the first time in Germany, at the end of the 1990s. In 2007, M-Pesa introduced an m-banking service based on text messages in Kenya (Shaikh and Karjaluoto, 2015). In the beginning of the 2000s, Brazilian banks began to invest in cell-phone-based services, first by making inquiries available and subsequently by offering transfer transactions, through solutions that required little browsing sophistication. The expansion of customer service to mobile phones enabled financial inclusion in Brazil, similar to what emerging countries in Africa and Asia have experienced (Corrêa da Fonseca, Meirelles and Diniz, 2010). Here in Brazil, though, m-banking services were treated as an extension of the banking channel and, behind the interaction with the clients, it still had the traditional business model as its base.

Shaikh and Karjaluoto (2015) propose a new definition for m-banking, closer to the concept of Open Banking being discussed around the world: "A product or service offered by a bank or micro financial institution or mobile network operator for carrying out financial and non-financial transactions using a mobile device, namely a cell phone, a smartphone or a tablet". The progression of traditional m-banking towards a more innovative service model is the result of three recent evolutions as of the second half of the 2000s. In the first place, the exponential growth of technologies that allow the transmission and processing of information in a fast and safe way, resulting in new business models with low initial investment. The second driver is the change in consumer preference. Currently, they are already familiar with digital interactions and used to experiences that are customized, user-friendly and cheap, usually in exchange for personal information. Finally, the advance of the regulatory model of the financial system and the digital world, which, on the one hand, imposed additional costs to financial services in relation to consumer protection and risk management practices, and, on the other hand, sought to increase competition within the industry. This combination opens up opportunities for emerging business models and new entrants (Ketterer, 2017). After more than 10 years - and with the entry of new actors into the financial and payment intermediation segments - banks began to perceive that there is a systemic change in the access to financial services that threatens the traditional model consolidated over the last 40 years (King, 2019).

\section{THE EMERGENCE OF OPEN BANKING}

Open Banking is the result of this convergence of technological, social and regulatory changes and may be defined as a new collaborative financial business model in which value is created as a result of the sharing of data, processes and capabilities of banks with an ecosystem of outsourced companies selected through application programming interfaces (APIs). This new model transforms the digital experience of the consumer allowing third parties to create complementary or disruptive products and services to meet the financial needs of individuals (Cortet and Stevens, 2018; Brodsky and Oakes, 2017). The vertically integrated traditional approach of financial conglomerates gives room to a platform model that reduces transaction costs and leverages network effects in which marginal gains increase for platform users as more users participate in the same platform. Bank-as-a-Platform (BaaP) is the answer to meet the demand created by Open Banking and banks will need to review their role as financial intermediaries. In the competition between banking platforms, the leaner ones and those providing the most attractive experience for the user and for the service developer will prevail and will reap the benefits arising from both the reduction in transaction costs and the network benefits (Zachariadis and Ozcan, 2017). 
Open Banking gains notoriety in 2016, when the United Kingdom's Competition and Markets Authority (CMA) published the report "Retail banking market investigation - final report", noting that traditional banks did not need to compete fiercely to do business with consumers and that smaller and newer banks had problems accessing the market. Mentioned 26 times in the text, the term "Open Banking" emerges as one of the solutions that will increase competitiveness of the British financial market, by allowing consumers, and small-sized and mid-sized companies to share their financial information with third parties as of 2018 (Open Banking Limited, 2019; CMA, 2016). This British regulatory framework is not isolated. There is a series of changes in the dynamics between regulators and the financial market in Europe, such as the approval of the Second Payment Services Directive (PSD2) and the General Data Protection Regulation (GDPR). These initiatives promote - in a mandatory way - the implementation of Open Banking in the European financial institutions, by opening financial data and transferring its control to the hands of the consumers. At the same time, in other countries, such as China and the United States, market forces gave rise to digital models of financial businesses in a more organic way. The neo-banks, a term that refers to innovative approaches to banking transactions in purely digital platforms and through social media - usually conducted by non-banking companies - may be found in these economies for a long time now. The early adopters, clients who engaged with these providers of financial services back in 2010, are now just regular folks looking for a more attractive transaction (King, 2014). As the client becomes more digital, their dynamic with their main provider of financial services - mostly large traditional banks - changes. The more digital a client is, the less is their future consumption inclination of a given product from their main provider of financial services, even if their trust in the institution increases (Schur, 2016). We may conclude that the Open Banking is not only an imposition of the regulation, but also a demand from the new digital native consumer as defined by Prensky (2001), such as those individuals who grew up with computers, videogames and mobile phones, all of them connected, whose behavior and preferences are different from those who learned to deal with this digital world, but who still maintain their connection with formats from the past. Almost twenty years later, this digital generation comprises an important portion of the mass of bank clients and they are the ones requesting an open banking model.

\section{SURVEY METHODOLOGY TO UNDERSTAND THE OPPORTUNITY FOR OPEN BANKING}

To understand the potential of this new dynamic of providing banking services in a collaborative way through a platform model, we will use the findings of a study organized by EY in 2018, available on https://www.ey.com/en_gl/open-banking-opportunity-index. The study Open Banking Opportunity Index calculated a comparative index between 10 countries considering four main pillars for the analysis of the Open Banking, defined here as sub-indexes: (i) the regulatory environment, evaluating how promising is the regulatory framework and the government policy to support an open banking system; (ii) the adoption potential, analyzing the prospects for consumers to adopt Open Banking; (iii) the consumer sentiment, evaluating how the population sees Open Banking and the sharing of financial data; and (iv) the innovation environment, understanding how receptive and firm is the landscape to promote innovation, particularly in relation to financial services (Thomas, Bellens and Claus, 2018). Between January and May 2019, EY Brazil complemented this study by including three countries from Latin America South: Argentina, Brazil and Chile. The results of this latest survey for Latin America South are the basis for this article.

For the consumer sentiment sub-index in the Latin America South countries, 3,028 respondents were interviewed, of which 1,004 were Argentinians, 1,024 Brazilians, and 1,000 Chileans, seeking to understand behavioral aspects in the consumption of digital financial products and services and the perception of these individuals regarding the Open Banking platforms. With 15 questions, the survey was answered electronically, and the data analyzed by each of the three countries individually. The demography of the sample surveyed is the following: (i) gender, $52 \%$ female and $48 \%$ male; (ii) age, $42 \%$ between 18 and 34 years old, $51 \%$ between 35 and 64 years old and $7 \%$ above 65 years old; (iii) income for the Brazilian sample, 17\% below 10,000 Brazilian Reais in the last 12 months (BRL/12mo), 29\% between 10,000 and 29,999 BRL/12mo, 30\% between 30,000 and 74,999 BRL/12mo and 25\% above 75,000 BRL/12mo; (iv) education, $2 \%$ primary school, $38 \%$ high-school, $50 \%$ university and $10 \%$ postgraduate. 


\section{BRAZILIAN CONSUMER SENTIMENT ANALYSIS REGARDING OPEN BANKING}

The 1,024 Brazilian consumers interviewed showed strong polarization in relation to the positive and the negative sentiment, when asked how they felt about the introduction of Open Banking, which will enable them to access new services, in exchange of sharing their personal bank account data with outsourced companies, such as FinTechs. Brazil has the fourth largest group of respondents with positive sentiment (33\%), but it is number one among the thirteen countries in terms of negative sentiment (16\%), resulting in an average net sentiment of $17 \%$. The results for the other countries were based on the findings of a study organized by EY in 2018 (Thomas, Bellens and Claus, 2018).

Table 1. Positive sentiment, negative sentiment and net consumer sentiment

\begin{tabular}{lccccc}
\hline \multicolumn{1}{c}{ COUNTRY } & RANKING & $\begin{array}{c}\text { NET } \\
\text { SENTIMENT }\end{array}$ & $\begin{array}{c}\text { POSITIVE } \\
\text { SENTIMENT }\end{array}$ & $\begin{array}{c}\text { NEUTRAL } \\
\text { SENTIMENT }\end{array}$ & $\begin{array}{c}\text { NEGATIVE } \\
\text { SENIMENT }\end{array}$ \\
\hline Australia & 1 & $37 \%$ & $40 \%$ & $57 \%$ & $3 \%$ \\
\hline China & 2 & $32 \%$ & $40 \%$ & $51 \%$ & $9 \%$ \\
\hline Singapore & 3 & $27 \%$ & $32 \%$ & $63 \%$ & $5 \%$ \\
\hline Netherlands & 4 & $23 \%$ & $30 \%$ & $62 \%$ & $8 \%$ \\
\hline Canada & 5 & $22 \%$ & $31 \%$ & $59 \%$ & $9 \%$ \\
\hline Hong Kong & 6 & $21 \%$ & $34 \%$ & $52 \%$ & $14 \%$ \\
\hline United States & 7 & $19 \%$ & $28 \%$ & $63 \%$ & $9 \%$ \\
\hline Spain & 8 & $18 \%$ & $20 \%$ & $78 \%$ & $16 \%$ \\
\hline Brazil & 9 & $17 \%$ & $33 \%$ & $51 \%$ & $12 \%$ \\
\hline United & 10 & $17 \%$ & $30 \%$ & $58 \%$ & $14 \%$ \\
Kingdom & & & & & $30 \%$ \\
\hline Germany & 11 & $9 \%$ & $23 \%$ & $52 \%$ & $30 \%$ \\
\hline Chile & 12 & $-12 \%$ & $18 \%$ & $55 \%$ & \\
\hline Argentina & 13 & $-14 \%$ & $16 \%$ & & \\
\hline
\end{tabular}

Considering age, net consumer sentiment is higher than the Brazilian average within the groups with age between 18 years old and 24 years old, and between 25 years old and 34 years old. The groups with age between 35 years old and 44 years old, between 45 years old and 54 years old, between 55 years old and 64 years old, and between 65 years old and 74 years old have a lower net sentiment than the Brazilian average. The net sentiment is also low for the group older than 75 years old, however this group is not significative in the sample. Considering income in the last 12 months, net consumer sentiment is higher within the groups with income between 30,000 and 49,999 Brazilian Reais over the last 12 months (BRL/12mo), between 75,000 and 99,999 BRL/12mo, and between 150,000 and 300,000 BRL/12mo. The net sentiment is also high for the group with the largest income, above 300,000 BRL/12mo, however this group is not significative in the sample. The group with income between 100,000 and 149,000 BRL/12mo has the same net sentiment as the Brazilian average. The groups with income between 50,000 and 74,999 BRL/12mo and below 30,000 BRL/12mo have a lower net sentiment than the Brazilian average. Table 2 presents the net sentiment of the sample of Brazilians per age group and per income group. 
Table 2. Positive sentiment, negative sentiment and net consumer sentiment

\begin{tabular}{|c|c|c|c|c|c|c|c|c|}
\hline \multicolumn{9}{|c|}{ AGE } \\
\hline $\begin{array}{l}\text { INCOME PER } \\
12 \text { MONTHS }\end{array}$ & $\begin{array}{c}18-24 \\
\text { years } \\
\text { old }\end{array}$ & $\begin{array}{c}25-34 \\
\text { years } \\
\text { old }\end{array}$ & $\begin{array}{c}35-44 \\
\text { years } \\
\text { old }\end{array}$ & $\begin{array}{c}45-54 \\
\text { years } \\
\text { old }\end{array}$ & $\begin{array}{c}55-64 \\
\text { years } \\
\text { old }\end{array}$ & $\begin{array}{c}65-74 \\
\text { years } \\
\text { old }\end{array}$ & $\begin{array}{l}75 \text { years } \\
\text { old or } \\
\text { above }\end{array}$ & Grand Total \\
\hline $\begin{array}{l}\text { Less than } \\
10,000 \text { BRL }\end{array}$ & $6 \%$ & $9 \%$ & $0 \%$ & $5 \%$ & $6 \%$ & $-10 \%$ & NA & $5 \%$ \\
\hline $\begin{array}{c}\text { 10,000 BRL - } \\
19,999 \text { BRL }\end{array}$ & $42 \%$ & $15 \%$ & $3 \%$ & $-8 \%$ & $-21 \%$ & $-40 \%$ & NA & $15 \%$ \\
\hline $\begin{array}{c}20,000 \text { BRL - } \\
29,999 \text { BRL }\end{array}$ & $40 \%$ & $44 \%$ & $3 \%$ & $-12 \%$ & $24 \%$ & $-11 \%$ & $0 \%$ & $16 \%$ \\
\hline $\begin{array}{c}\text { 30,000 BRL - } \\
49,999 \text { BRL }\end{array}$ & $39 \%$ & $11 \%$ & $30 \%$ & $28 \%$ & $21 \%$ & $17 \%$ & NA & $23 \%$ \\
\hline $\begin{array}{c}50,000 \text { BRL - } \\
74,999 \text { BRL }\end{array}$ & $13 \%$ & $46 \%$ & $15 \%$ & $4 \%$ & $8 \%$ & $9 \%$ & NA & $16 \%$ \\
\hline $\begin{array}{c}\text { 75,000 BRL - } \\
99,999 \text { BRL }\end{array}$ & $50 \%$ & $25 \%$ & $22 \%$ & $32 \%$ & $17 \%$ & $20 \%$ & $-33 \%$ & $25 \%$ \\
\hline $\begin{array}{c}100,000 \text { BRL - } \\
149,999 \text { BRL }\end{array}$ & $100 \%$ & $38 \%$ & $42 \%$ & $10 \%$ & $3 \%$ & $-20 \%$ & $100 \%$ & $17 \%$ \\
\hline $\begin{array}{c}150,000 \text { BRL - } \\
300,000 \text { BRL }\end{array}$ & $100 \%$ & $18 \%$ & $17 \%$ & $50 \%$ & $27 \%$ & $20 \%$ & NA & $29 \%$ \\
\hline $\begin{array}{c}\text { More than } \\
\mathbf{3 0 0 , 0 0 0}\end{array}$ & $100 \%$ & $67 \%$ & $100 \%$ & NA & $50 \%$ & $0 \%$ & NA & $64 \%$ \\
\hline Grand Total & $31 \%$ & $23 \%$ & $15 \%$ & $12 \%$ & $12 \%$ & $-3 \%$ & $0 \%$ & $17 \%$ \\
\hline
\end{tabular}

SCALE

\begin{tabular}{l|l|l|l}
$<24 \%$ & $25 \%-40 \%$ & $50 \%-74 \%$ & $75 \%-100 \%$
\end{tabular}

In general, the younger the person and the higher their income over the last 12 months, the more they show positive sentiments in relation to Open Banking. And the higher their age and the lower their income, the more intense are their negative sentiments. Within the age and income segments analyzed, we found an intermediate range whose negative sentiment is above the Brazilian average, outside the trend found. Considering age, the negative sentiment is above the Brazilian average for the group between 35 years old and 44 years old in addition to the groups between 65 years old and 74 years old, and above 75 years old. Considering income, the negative sentiment is above the Brazilian average for the groups between 150,000 BRL/12mo and 300,000 BRL/12mo, and between 100,000 BRL/12mo and 149,999 BRL/12mo, in addition to the groups between 10,000 BRL/12mo and 19,999 BRL/12mo, and below 10,000 BRL/12mo. This is an important aspect, as these intermediate age and income groups comprise the country's most active groups in terms of usage of retail banking services. We do not have the answers for the reasons why the negative sentiment is out of step within these groups, but it is possible that this occurs because people with these profiles have higher probability of using digital financial services and may had negative experiences.

The positive sentiment comes from the perception of the benefits that an Open Banking profile will bring to their daily lives. $30 \%$ of the respondents believe that with Open Banking they may access more banking services through their cell phones, 29\% think Open Banking may help reduce banking rates and tariffs, and $27 \%$ expect that innovative services will be created. The negative sentiment is associated with potential losses related to the use of the open platform. 36\% intend to keep their banking data as private as possible, $31 \%$ are worried about the increase in cyber risks and $30 \%$ believe that they will be more exposed to payment fraud (Pleszowski and Schur, 2019).

\section{CONCLUSION}

With 1,024 respondents, the survey conducted in the beginning of 2019 indicated that the sentiment of Brazilian banking consumers is positive regarding the use of online financial services in an open platform model - in line with the Open Banking concept that will be regulated in Brazil based on Announcement No. 33.455 of the Brazilian Central Bank. Several of these consumers already have some experience with 
FinTech services and those who have use this service frequently. Both the net consumer sentiment regarding Open Banking and the use of FinTech services are higher among the younger population - mostly digital natives, who seek innovative solutions for their financial needs. The assessment indicates that the adoption of digital banking services based on an open platform will be higher, the higher are the assurances to consumers regarding their privacy and the risk management of third parties who connect to the platform. Another equally important challenge is the need to expand the technological environment with more broadband access and higher usage of smartphones, which will enable Open Banking to reach a wider spectrum of the Brazilian population. New studies to evaluate in further detail the incentives and barriers for the adoption of banking services in an open platform and, as a result, to analyze the business model alternatives that financial institutions may adopt and that the Brazilian Central Bank should regulate will certainly contribute for the effective implementation of Open Banking in Brazil in the short term.

\section{ACKNOWLEDGEMENT}

This paper and the research behind it would not have been possible without the exceptional support of EY.

\section{REFERENCES}

Brazilian Central Bank. (2019). Announcement No. 33.455. available on: https://www.bcb.gov.br/estabilidadefinanceira/exibenormativo?tipo=Comunicado\&numero $=33455$

Brodsky, L.; Oakes, L. (2017). Data sharing and open banking, McKinsey on Payments.

Competition \& Markets Authority. (2016). Retail banking market investigation - final report. Available on: https://assets.publishing.service.gov.uk/media/57ac9667e5274a0f6c00007a/retail-banking-market-investigation-fullfinal-report.pdf

Corrêa da Fonseca, C. E.; Meirelles, F. S.; Diniz, E. H. (2010). Tecnologia bancária no Brasil: Uma história de conquistas, uma visão de futuro. Edição Comemorativa de 20 anos do Ciab FEBRABAN. FGV RAE.

Cortet, M.; Stevens, A. (2018). Mastering open banking: How the 'masters in openness' create value. Innopay Whitepaper. Available on: https://www.innopay.com/en/publications/mastering-open-banking-how-mastersopenness-create-value

EY. (2018). EY open banking opportunity index 2018 - methodology. Available on: https://assets.ey.com/content/dam/eysites/ey-com/en_gl/topics/banking-and-capital-markets/EY-open-banking-opportunity-index-methodology.pdf

Ketterer, J. A. (2017). Digital finance: New times, new challenges, new opportunities. Inter-American Development Bank, Discussion Paper No. IDB-DP-501. Available on: https://publications.iadb.org/en/digital-finance-new-timesnew-challenges-new-opportunities

King, B. (2014). Breaking banks: The innovators, rogues, and strategists rebooting banking. John Wiley \& Sons Singapore Pte. Ltd., 165-196.

King, B. (2019). Bank 4.0: Banking everywhere. Never at a bank. Marshall Cavendish International (Asia) Pte. Ltd., 13-15, 186-218.

Open Banking Limited. (2019). Background to open banking. Available on: https://www.openbanking.org.uk/about-us/

Pleszowski, D.; Schur, R. D. (2019). Why building consumer trust is key to Brazil's open banking success. EY. Available on: https://www.ey.com/en_gl/banking-capital-markets/why-building-consumer-trust-is-key-to-brazil-open-bankingsuccess

Prensky, M. (2001). Digital natives, digital immigrants. On the horizon. MCB University Press, Vol. 9, No. 5

Schur, R. D. (2016). Global consumer banking survey - análise da indústria bancária no Brasil em comparação com o mundo. EY. Available on: https://www.ey.com/Publication/vwLUAssets/EY-Global-Consumer-Banking-Survey2016/\$File/Global-Consumer-Banking-Survey-2016-27-07-2017-Pagina-Simples-003.pdf

Shaikh, A.; Karjaluoto, H. (2015). Mobile banking adoption: A literature review. Telematics and Informatics, 32 (1). Available on: doi:10.1016/j.tele.2014.05.003

Thomas, H.; Bellens, J.; Claus, K. C. (2018). Open Banking Opportunity Index: where open banking is set to thrive. EY. Available on: https://www.ey.com/en_gl/banking-capital-markets/ey-open-banking-opportunity-index-where-openbanking-is-set-to-thrive

Zachariadis, M.; Ozcan, P. (2017). The API economy and digital transformation in financial services: The case of open banking. SWIFT Institute Working Paper No. 2016-001. Available on: https://ssrn.com/abstract=2975199 